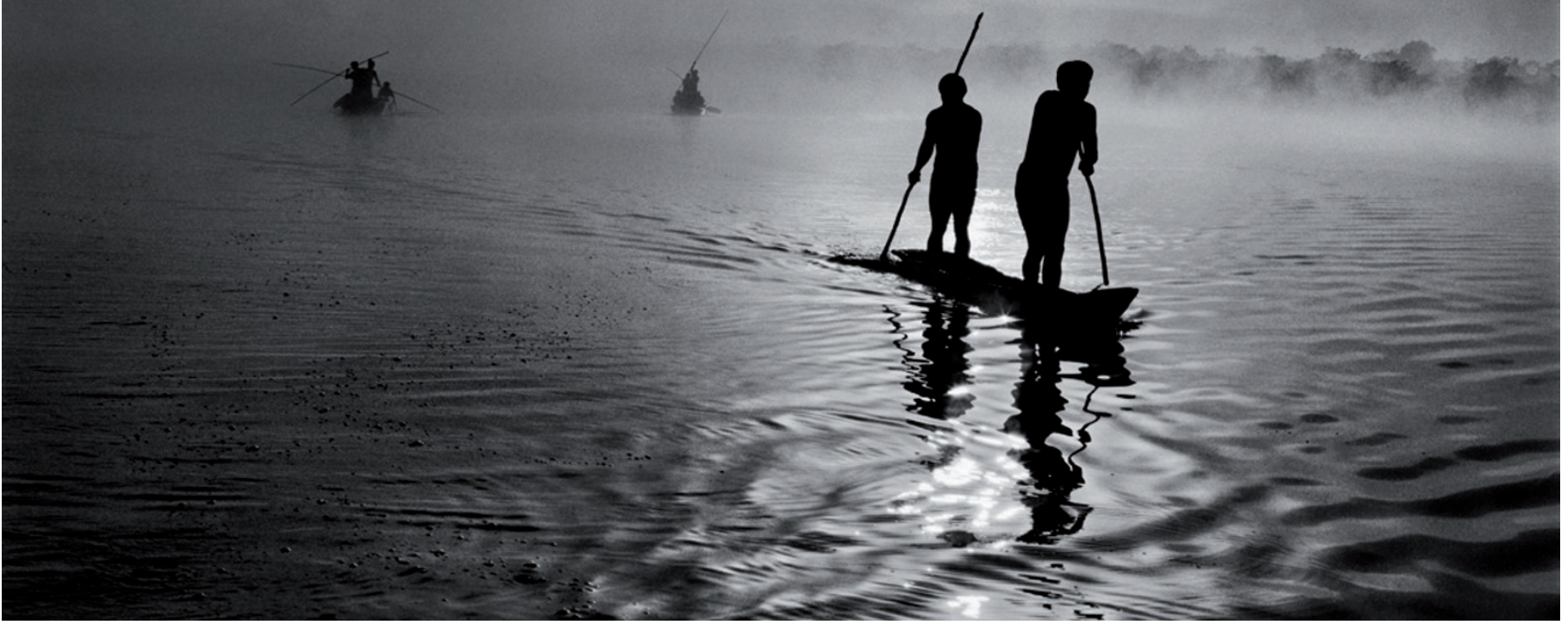

Waura tribesmen fish in the Piulaga lake near their village in the Upper Xingu region of Brazil's Mato Grosso state.

\title{
A monochrome Eden
}

\section{Bob Bloomfield assesses a haunting photographic record of remote environments and the indigenous peoples who live in them.}

$\mathrm{T}$ he celebrated Brazilian documentary photographer Sebastião Salgado is best known for his black-and-white images of the Serra Pelada gold mine in Brazil, shot in 1986. Those stark photographs of mud-encrusted workers toiling through the labyrinthine open mine workings highlighted the appalling working conditions. Now, after decades of social observation, Salgado has turned his lens on the environment, to convey how its degradation has led to much of the inequity he has recorded.

Genesis is a project eight years in the making - the culmination of journeys across 32 countries to document remote ecosystems and local peoples whose survival now hangs by a thread. The 250 photographs on show at London's Natural History Museum are part of a portfolio that is touring venues around the world. Salgado calls his new work Genesis because he wanted to record "the animal species that have resisted domestication" and the "remote tribes whose 'primitive' way of life is largely untouched". He hopes that by highlighting this "uncontaminated world" he can help it to be preserved and, where degraded, restored. His vision is Sebastião that development need Salgado: Genesis not be synonymous WATERHOUSE with destruction.

The images include breathtaking vistas across Siberian wastes, GALLERY, NATURAL HISTORY MUSEUM, LONDON 11 April to 8 September 2013 in verdant Amazonian forested valleys, over the haunting Namibian dune fields and among the animals at home in the harsh beauty of Antarctica. He spent time with local peoples, including the Xingu in the upper Amazon, the Bushmen in Botswana and the Dinkas in Sudan. There are striking records of daily life: foraging, making fires, preparing food, socializing and sharing ritual celebrations.

Salgado provides no contrasting images of the globalized world, dominated by urban expansion and the conversion of natural land for burgeoning infrastructure, transportation, extraction and agro-forestry. Nor, in hymning the intrinsic beauty of wilderness, does he draw attention to those regions' wider value as vital 'organs of the biosphere', contributing to the planet's regulatory system. There is instead a nostalgia for a halcyon disappearing world - worthy and understandable, but saying little about the broader imperative to protect global wilderness and biodiversity.

Similar issues cloud the portraits. Salgado spent time with the people he recorded, and the images were taken with their consent. Yet his photographs of proud people seem to be coloured by the Arcadian ideals of the late eighteenth century - a vision of 'noble savages' populating an Eden somehow preserved from the ravages of civilization. In part because of the likeness of the blackand-white images to old sepia photographs, I found myself reminded of colonial and ethnographic photographic archives.

Today, our understanding of indigenous peoples is more nuanced. Even though they may be profoundly culturally adapted to their environments, their 'sustainable' lifestyles often come at a price, such as high child mortality or relatively short lifespans. And whereas many indigenous cultures are seriously threatened by outside forces, many are increasingly proactive in fighting for their traditional and customary rights 
to the land, and are adopting new ideas and technologies on their own terms.

For example, in Brazil, the Kaxinawá live in the state of Acre in the western Amazon, where forest covers $88 \%$ of the land but indigenous groups control only $1.5 \%$ of it. Kaxinawá elders are working with the state government to ensure official recognition of and compensation for their traditional stewardship of the forests. In Ecuador, the Huaorani, whose lands are under threat from logging and oil interests, are using geographic information system technology and traditional knowledge to map areas for potential tourism and conservation, creating a community resource for planning and negotiating. There is nothing of this side of the story in Genesis.

Salgado spends time on the Atlantic coast of Brazil, home to one of the most biodiverse forest ecosystems in the world, the highly threatened Atlantic Forest (Mata Atlântica), of which only small fragments survive. With his wife, Lélia Deluiz Wanick, Salgado has been restoring a denuded 630-hectare site near Aimorés by planting trees and reintroducing other species. They have also founded the Instituto Terra, an initiative that supports the environmental education of Brazilian officials, teachers and farmers, and aims to show that it is possible to restore environments that seemed lost forever.

Although Genesis brings into sharp focus the need to preserve both the wilderness and the well-being of the peoples relying on it, the role of the outside world is more ambiguous. Both the Atlantic Forest project and the exhibition are supported by the Brazilian multinational Vale, based in Rio de Janeiro, one of the biggest construction and mining companies in the world. Its website states that "it is committed to quality of life and environmental preservation". However, some indigenous peoples and human-rights groups oppose Vale's stakes in major dam and mining projects in the Amazon interior.

If Genesis gets people to reconsider the value of the disappearing wild, it will have achieved an important aim. If it promotes discussion on the plight of indigenous peoples, their self-determination and their potential as stewards of wilderness crucial to our future, it will have offered an invaluable revelation. But however visually stunning and moving these images are, to me they reduce the complex realities for local people and remote environments of our changing world to black and white, rather than shades of grey.

Bob Bloomfield is an independent expert, based in the United Kingdom, on public engagement and understanding of science and environment, and formerly in the Public Engagement Executive of London's Natural History Museum.

e-mail:bob_bloomfield@bobania.f9.co.uk

\section{Books in brief}

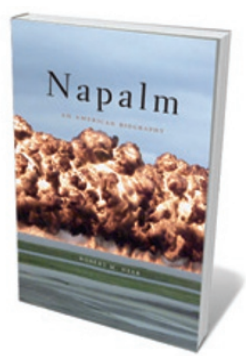

Napalm: An American Biography

Robert M. Neer HARVARD UNIVERSITY PRESS 352 pp. \$29.95 (2013)

In 1942, in a secret lab at Harvard University in Massachusetts, chemist Louis Fieser and his team created napalm — an incendiary gel that sticks to skin and can burn down to the bone. Robert Neer's harrowing story veers from Fieser's tests on 'kamikaze' bats fitted with napalm bombs to the 1944-45 incendiary bombing of Japan that killed 330,000 people. In 1980, the United Nations declared the gel's use on concentrations of civilians a war crime. An interview with Phan Thi Kim Phuc — photographed running naked and napalm-burned during the Vietnam War - underlines the cost of miscast innovation.

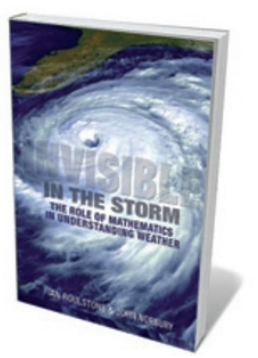

Invisible in the Storm: The Role of Mathematics in Understanding Weather

lan Roulstone and John Norbury PRINCETON UNIVERSITY PRESS 346 pp. $\$ 35$ (2013)

Mathematicians lan Roulstone and John Norbury demystify the maths behind meteorology. Trailblazers' work is vividly evoked, from eighteenth-century mathematician Leonhard Euler on hydrostatics to physicist Vilhelm Bjerknes's numerical weather prediction. The pace cranks up with twentieth-century advances such as Jule Gregory Charney's harnessing of the gargantuan ENIAC computer for his work in the 1940s and 1950s on forecasting pressure patterns.

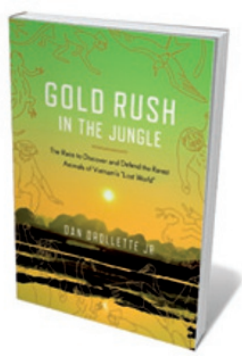

Gold Rush in the Jungle: The Race to Discover and Defend the Rarest Animals of Vietnam's "Lost World"

Dan Drollette Jr CROWN 336 pp. \$25 (2013)

From elusive forest oxen to barking deer, Vietnam has seen a raft of newly discovered species emerge during the past decade. Almost as swiftly, the black market is bringing many close to extinction. Science journalist Dan Drollette Jr reveals the courage and ingenuity of researchers intent on preserving what wildlife they can. Drawing on years of visits to the country, his snapshots of these wild life warriors — such as langur specialist Tilo Nadler — reveal approaches that could show the way for conservationists in other tight spots.

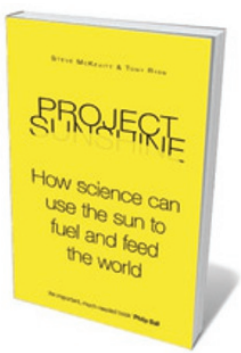

Project Sunshine: How Science Can Use the Sun to Fuel and Feed the World

Tony Ryan and Steve McKevitt ICON 320 pp. £16.99 (2013)

Polymer chemist Tony Ryan and consumerism expert Steve McKevitt train a ray of sunshine on the issues of food and energy security. They argue - and are backed by a major research project at the University of Sheffield, UK — that a "solar economy" can sustainably support the world population of 9 billion people predicted for 2050. Cogently analysing business as usual won't work; the authors lay out a science-based, multi-pronged solution incorporating measures such as state-of-the-art photovoltaics.

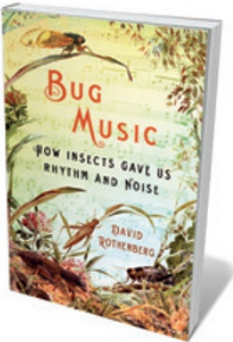

Bug Music: How Insects Gave Us Rhythm and Noise

David Rothenberg ST MARTIN'S PRESS 288 pp. \$26.99 (2013) Philosopher and musician David Rothenberg asks whether the tapping, clicking, humming leitmotifs of the insect world inspired human rhythm. The result mixes research on insect behaviour and anatomy, sonograms and more with apt artistic digressions. From the deafening 'surround-sound' of the 17-year cicada Magicicada cassini to syncing crickets, vibrating three-humped treehoppers and the "penile music" of water boatmen, this is an enchanting foray into the "polyrhythmic swirls of the entomological soundscape". 